\title{
MEDEDELING VAN DIE REDAKSIE
}

Nadat die firma J. H. de Bussy sedert die begin van die bestaan van die Hervormde Teologiese Studies in 1943 as Uitgewer opgetree het, het die Redaksie met volle medewerking van hierdie Ulitgewer daartoe besluit om die uitgawe voortaan toe te vertrou aan die Nederduits Hervormde Weeshuis-Pers te Krugersdorp. Die Redaksie waardeer die dienste van die vorige Uitgewer ten hoogste en wil hierby sy welgemeende dank uitspreek vir al die arbeid en sorg wat die firma de Bussy aan die uitgawe gewy het byna twaalf jare lank. Dat ons Studies wat as 'n wetenskaplike tydskrif uiteraard nie oor 'n groot aantal intekenaars beskik nie en as teologiese uitgawe nie juis deur die rykes van die aarde in stand gehou word nie, gereëld en nou reeds in sy elfde jaargang kon verskyn het, is seker vir 'n groot deel te danke aan die toewyding van die Uitgewer. Ons wil hier uitdruklik die naam van die huidige bestuurder van die Pretoria-tak van de Bussy, mnr. $M$. Verduyn, noem, wat persoonlik steeds 'n lewendige belangstelling getoon het in die inhoud van die Studies en vir 'n keurige uiterlike verskyning daarvan gedurig sorg gedra het. Dat die oordrag van uitgewersregte en -verpligtinge so gemaklik verloop het, is seker vir 'n groot deel aan sy vlotte medewerking te danke.

Die Redaksie waardeer dit besonder dat die Ned. Herv. Weeshuis-Pers, verteenwoordigd in die persoon van sy besturende direkteur, mnr. A. B. van N. Herbst, hom so geredelik bereid verklaar het om die werk van die uitgawe oor te neem. Waar reeds by ver die meeste van die gereëlde uitgawes van die Kerk deur die Weeshuis versorg word, het dit voor die hand gelê dat ook die uitgawe van die Hervormde Teologiese Studies, hoewel nie direk 'n kerklike publikasie nie, deur dié Pers behartig sou word-temeer omdat die N.H.W.Pers van die genoemde uitgawes so 'n klaarblykelike sukses gemaak het. As ons bedink watter groot en geseënde werk die in Nederland so welbekende Neerbosch Weeshuis ook op die gebied van uitgewery. drukkery en boekhandel verrig het, kan ons hoop en vertrou dat die N.H.W.-Pers net so ' $n$ weldaad vir Kerk en volk van Suid-Afrika sal wees.

Ons hoop en vertrou ook dat ons intekenaars ewe getrou as totnoutoe sal help om die uitgawe voort te sit en indien moontlik selfs uit te brei. Miskien mag ons op nog meer medewerking en nog getrouer ondersteuning as in die verlede reken. Vir gereëlde drie- 
maandelikse verskyning sal die Redaksie en die Uitgewer alle middele in die werk stel. Ons doen 'n beroep op almal wie die bevordering van die Bybels-Reformatoriese Teologie in Suid-Afrika ter harte gaan om die Studies nog meer as totnogtoe aan sy bestemming te laat beantwoord deur abonnemente te behou en te vermeerder, deur getrou die geldelike verpligtings te vereffen, deur nougesette lees en bespreek van sy inhoud en by die Redaksie daarop te reageer, asook deur die instuur van bydraes in geskrifte en aktuele medewerking aan sy inhoud.

Uitgewers van teologiese geskrifte in Suid-Afrika en oorsee word opnuut hartlik uitgenooi om hulle publikasies vir bespreking in te stuur. Die Redaksie lê hom in die besonder op deeglike en pronte resensering van dergelike uitgawes toe.

Mag die God van alle wysheid en liefde $U$ en ons by die voortsetting van hierdie arbeid vir sy Ryk seën.

Namens die Redaksie.

B. Gemser, Voorsitter.

B. J. Engelbrecht, Sekretaris. 